\title{
A GAMIFIED MODEL FOR THE CONSTRUCTION SITE: A SOLUTION TO MOTIVATE CONSTRUCTION WORKERS IN PANDEMIC TIME
}

\author{
Regina Maria Cunha Leite ${ }^{a b}$, Lynn Rosalina Gama Alves ${ }^{c, a}$ \\ a SENAI-CIMATEC - Doctoral program in management and industrial technology \\ ${ }^{b}$ Federal Institute of Bahia, Department of Civil Construction, Campus Salvador, \\ Bahia, Brazil \\ ${ }^{c}$ Federal University of Bahia, Institute of Sciences and Humanities- Bahia, Brazil
}

\begin{abstract}
This article aims to present the first results of a study that investigates how construction companies can use gamification to help workers assume appropriate behaviors and motivate construction teams to achieve their production goals. It is an exploratory, empirical, qualitative research, whose methodological approach is Design Science Research. To understand the context of works, a closed questionnaire was carried out to construction workers. This tool aims to investigate motivational aspects and another, with engineers, aims to identify which production problems to support a proposal for a gamified model. The results show that most workers have a need to be recognized and that the proposed solution can contribute to the continuous improvement of the work environment.
\end{abstract}

Keywords: Gamification; Motivation; Production Control; Construction.

\section{UM MODELO GAMIFICADO PARA O CANTEIRO DE OBRAS: UMA SOLUÇÃO PARA MOTIVAR TRABALHADORES DA CONSTRUÇÃO EM TEMPO DE PANDEMIA}

\section{Resumo:}

Este artigo tem como objetivo apresentar os primeiros resultados de uma pesquisa que investiga como as empresas de construção civil podem usar a gamificação para ajudar trabalhadores a assumirem comportamentos apropriados e motivar equipes de obras a alcançarem suas metas de produção. Trata-se de uma pesquisa exploratória, empírica, qualitativa, cuja abordagem metodológica é o Design Science Research. Para entender o contexto de obras realizou-se um questionário fechado com operários da construção civil, a fim de investigar aspectos motivacionais e outro, com engenheiros, para identificar os problemas de produção para subsidiar uma proposta de um modelo gamificado. Após a análise dos dados, foi possível verificar que os operários possuem necessidade de serem reconhecidos e que a solução proposta pode contribuir para a melhoria contínua do ambiente de obra. 
Palavras-chave: Gamificação; Motivação; Controle da Produção; Construção civil.

\section{INTRODUCTION}

In 2020 the world is experiencing a pandemic never imagined. Everyone was preparing for a nuclear war, but it was never thought that a small virus could alter the routine of all the peoples of the planet. Researchers from all over the world started to look for a vaccine [1]. It has already been discovered and is in production. The question is: "After this COVID-19 pandemic, will we have others? What will everyday life be like after COVID-19?" Certainly, there will be changes and learning in all sectors that will remain forever. More specifically, in the Civil Construction sector: "How will the adaptation to the new normal be?"

In the context of Civil Construction, since the emergence of Lean Construction [2], the construction industry has been pursuing the efficient implementation of lean production in construction sites. Lean practices are deeply connected to human behavior, and there is no way to separate their effects. Furthermore, at the construction site, the projects are complex and involve several intervening factors that work simultaneously, often resulting in unnecessary rework, movement of people, and material handling.

Thus, despite the discussions about lean construction [3-5], the reality of the construction site is still characterized by presenting an environment where communication between managers and workers is deficient, the workforce is rotating and little engaged, the workers perform manual and repetitive work [6], have a low qualification and education. Furthermore, the diversity of services and the dynamic way in which they take place, makes production control a complex activity, making it arduous to meet the goals set in the planning [7].

So, one of the significant challenges of the construction is to control its processes so that they occur as planned and, if something different from the programmed one, it is possible to identify the deviations quickly and make improvements. These actions and their results on a construction site directly involve the performance of workers. Consequently, the importance of investing in improvements in working conditions is evident, since the satisfaction and well-being of workers will reflect in more dedication and commitment to the performance of their duties.

Construction companies generally have few visual mechanisms to inspire, motivate, or instruct workers to do their jobs more effectively, efficiently, and safely [8]. There is a need for structures to facilitate the feedback process to the worker and to make the relevant information transparent to them [8]. Little feedback on the work in progress and the performance of the workers involved in the process leads to low engagement at the construction site and makes it difficult to meet production goals effectively [9].

It is in this context that gamification, defined as the insertion of game elements in non-game contexts [10], appears as an innovative idea to improve communication between managers and workers, promoting motivation and engagement. The strategy aims to motivate the worker to perform repetitive tasks, encouraging him to assume 
the player's behavior. So, how can gamification strategies improve production control and workers' motivation at the construction site?

The purpose of this article is to present the first results of a research that investigates, through Design Science Research, how construction companies can use technology to involve and help workers to assume appropriate behaviors and motivate construction teams to achieve their goals, incorporating game elements into applications and processes through gamification.

\subsection{Gamification}

There are many definitions for the term gamification [10-12], Deterding refers to gamification as adding game mechanisms to everyday life contexts to provide fun experiences and improve the motivation of those involved. It is important to note that, despite the use of game elements, gamified applications are not exactly games. Gamification is usually used to influence human motivation and behavior positively [1316].

Therefore, several game strategies can be used in gamification, such as Avatars, Teammates, Points, Badges, Leaderboards, Narrative, Performance Charts, Rewards, Voting, Bets, Levels, Missions, Progress Bar, Collaboration, Unlocking content, Rules, Online Store, Missions, Deadline and Feedback [16-21].

Chou [20] states that most systems are designed to facilitate tasks to be performed in the shortest possible time. Therefore, during the design phase, it is necessary to consider that the people who perform these activities have emotions, insecurities, and opinions about what is expected of them, or about how they should achieve their professional goals.

Deterding [22] presents two rhetoric for the conception of a gamification process: (1) Rhetoric of chosen architecture that presents human beings with rational and strategic agents and gamification as an information system with incentives. This rhetoric launches gamification as a refinement of existing business practices. (2) Humanist rhetoric is based on positive design psychology and virtue ethics. This rhetoric believes that human beings are social, emotional creators of meaning and oriented towards growth. It is directly focused on the well-being of the worker.

\subsubsection{Gamification in production}

In 2012, Korn \& Schmidt [23] introduced the first concept of gamification in industrial workplaces. In the motionEAP research project (2013-2016), ways of improving assistance systems in production environments are explored. In parallel, in the same year, Leite [24] began his studies of gamification at the construction site. The research by Korn \& Schmidt [23] proposes the implementation of gamification elements as an avatar, uses color-coding to visualize the progression of time, especially for the automobile industry. In contrast, Leite's research [26] uses elements such as points, ranking, and leaderboards to motivate workers to comply with weekly planning goals.

Warmelink et al. [25], present a Systematic Literature Review (SLR) on gamification in industrial production for the period from 2012 to 2017 . SLR was carried 
out in May 2017. This review results in only sixteen studies, of which twelve were developed by Korn \& Schmidt [23] and two by Leite [6] and Moreda Neto [9]. This highlights the research gap in the production area.

\section{METHODOLOGY}

Design Science Research was selected as the most appropriate methodological approach for the development of this work because it is used in research whose objective is to create, develop, and explore new solutions [26]. In this case, it is an exploratory, empirical, qualitative research to evaluate strategies to improve production control and engagement of construction workers through the creation and implantation of a gamified artifact. The research consists of 4 phases: (1) Understanding phase, (2) Development phase, (3) Analysis phase, and (4) Phase of evaluations and reflections, this article presents the implementation proposal that corresponds to the dashed line in the Figure1.

Figure 1: Research Outline

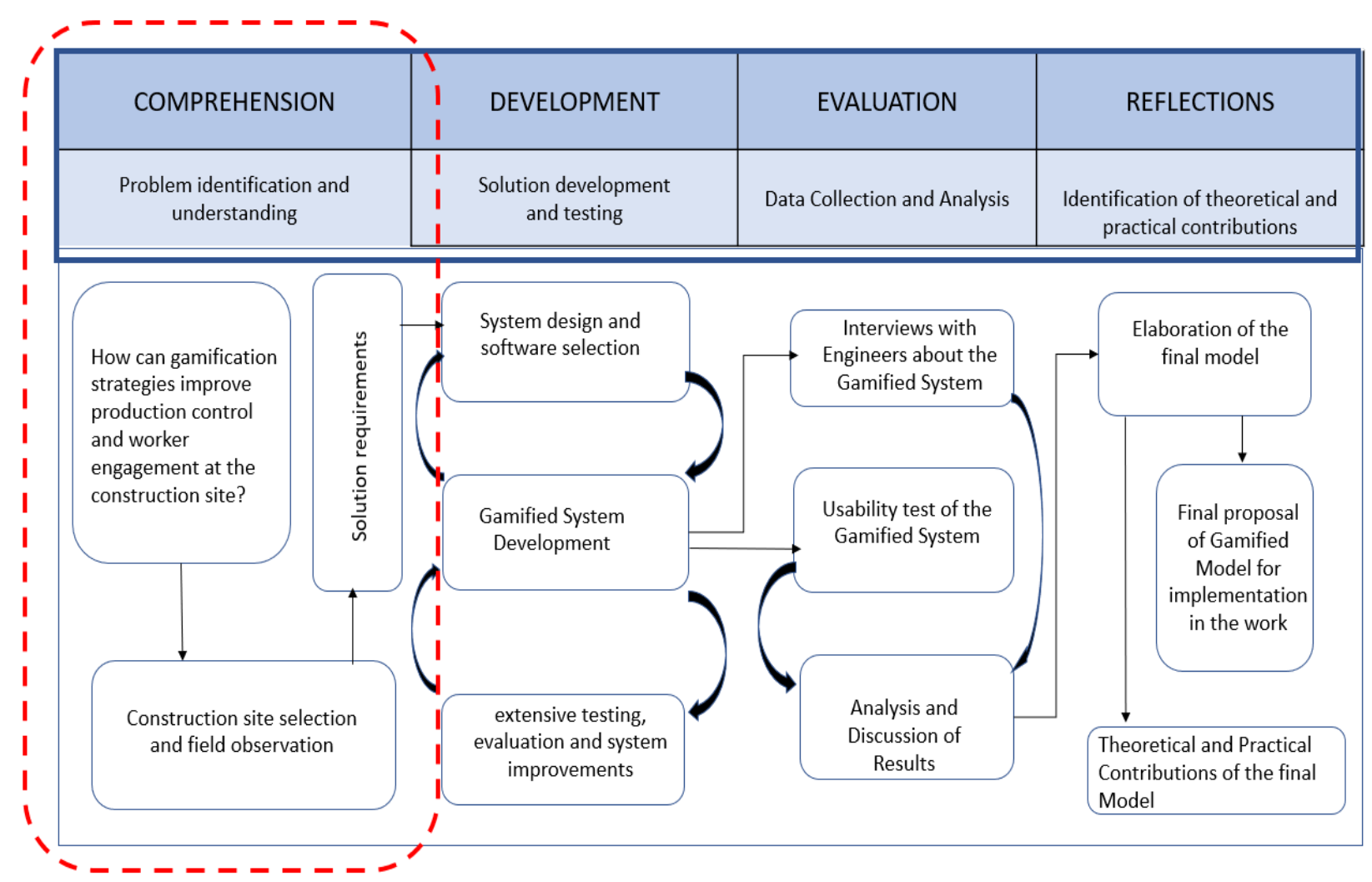

Source: Research method of the author's doctoral thesis project

In the phase of understanding the problem, starting from the bibliographic review carried out in the first stage, the knowledge gap that gave rise to the identification of the real problem was identified; for this, an exploratory study was carried out. Contact was made with two companies that practice lean construction in their construction sites. The two sites were visited to survey requirements, plan, and understand the process for gamification.

Focusing of the problem defined in the previous step, we used data from the research on motivation developed by the research group GCIS-IFBA, the result of the 
application of questionnaires with the research subjects (supervisors and workers) seeking to better understand the following points: (1) What does the worker, the gamification user, expect from the process? (2) What would motivate him to participate in gamification? (3) What does the company, an environment to be gamified, need? (4) What are the desired behaviors to be motivated by gamification? These questions served to guide the survey of requirements for the gamified solution.

From this knowledge, it was possible to perform the selection of software and hardware to develop the artifact and prepare the first proposal of the model.

\section{RESULTS AND DISCUSSION}

Understanding the current situation is the first step to be taken towards solving the problem. For this, an exploratory study was carried out to obtain a requirements survey and selection of software and hardware for the proposed elaboration of a model for solving the problem.

\subsection{The preliminary exploratory study}

The exploratory study had two objectives: (1) identify the needs of workers and engineers to insert gamification strategies on the construction site; (2) know the characteristics of the workers. For this, questionnaires were conducted with the target audience that had the following samples:

109 respondent workers, being 108 male and 1 female. Average age group: 35.76 years. Education: $46.8 \%$ have an incomplete elementary school, $27.5 \%$ of the public have a complete elementary school, and $25.7 \%$ of the public have a complete secondary school. Composition: 59 professionals, 42 helpers, and 13 servants. The empirical space was the construction site. received.

- Engineers with experience ranging from 5 to 35 years. 26 responses were

After analyzing the questionnaires with the workers, it can be understood that:

They like what they do; the majority $(51.4 \%)$ show a considerable lack of recognition. Everyone said that they like to play, especially Football, Cards, and Dominoes. They prefer to work as a team. They usually play using the smartphone. They extensively use WhatsApp, Facebook, and Instagram. They understand that fun is something pleasurable, and that is part of everyday life. They liked the idea of gamification and want to participate.

As for the engineers (supervisors): They believe that gamifying is interesting to improve the progress of the work and the motivation of the worker. Only $30 \%$ have daily information on worker productivity. Most engineers $(96.2 \%)$ believe that the idea of giving feedback to workers is a good one and that it would increase motivation. The use of mechanisms that will motivate workers to carry out their activities to their full potential is well accepted. They liked the idea of gamification and would adopt it at work. $65 \%$ said their companies want to retain employees.

\subsection{Proposal for the Gamified Model}

A mobile device gamified system will be designed to give feedback to the worker on his performance from the data collected in the monitoring of the services. Rules will be developed, together with the project managers, so that the gamified system can 
assess the worker's performance. Gamification may use points, avatars, and other game mechanisms to encourage participation and improve performance. Only the worker will know his performance.

A gamified interface presented on a monitor strategically installed in the workplace will show the performance of construction teams and the weekly progress of services. This service will be monitored by the site supervisor.

To act in post-COVID-19 times, individual controls may be necessary, such as the use of masks, frequent hand washing, and or use of alcohol, keeping time out regulated by the World Health Organization and others. In this case, each need can be transformed into a gamification rule. The control of these rules can be done by placing a camera in the place available for handwashing. The distance can be measured by an application using the cell phones themselves. The system to be developed must be very flexible in terms of creating rules, so new rules in the event of a pandemic will be easy to implement. Figure 2 presents a general scheme of the gamified model.

Figure 2: General gamification information scheme at the construction site.

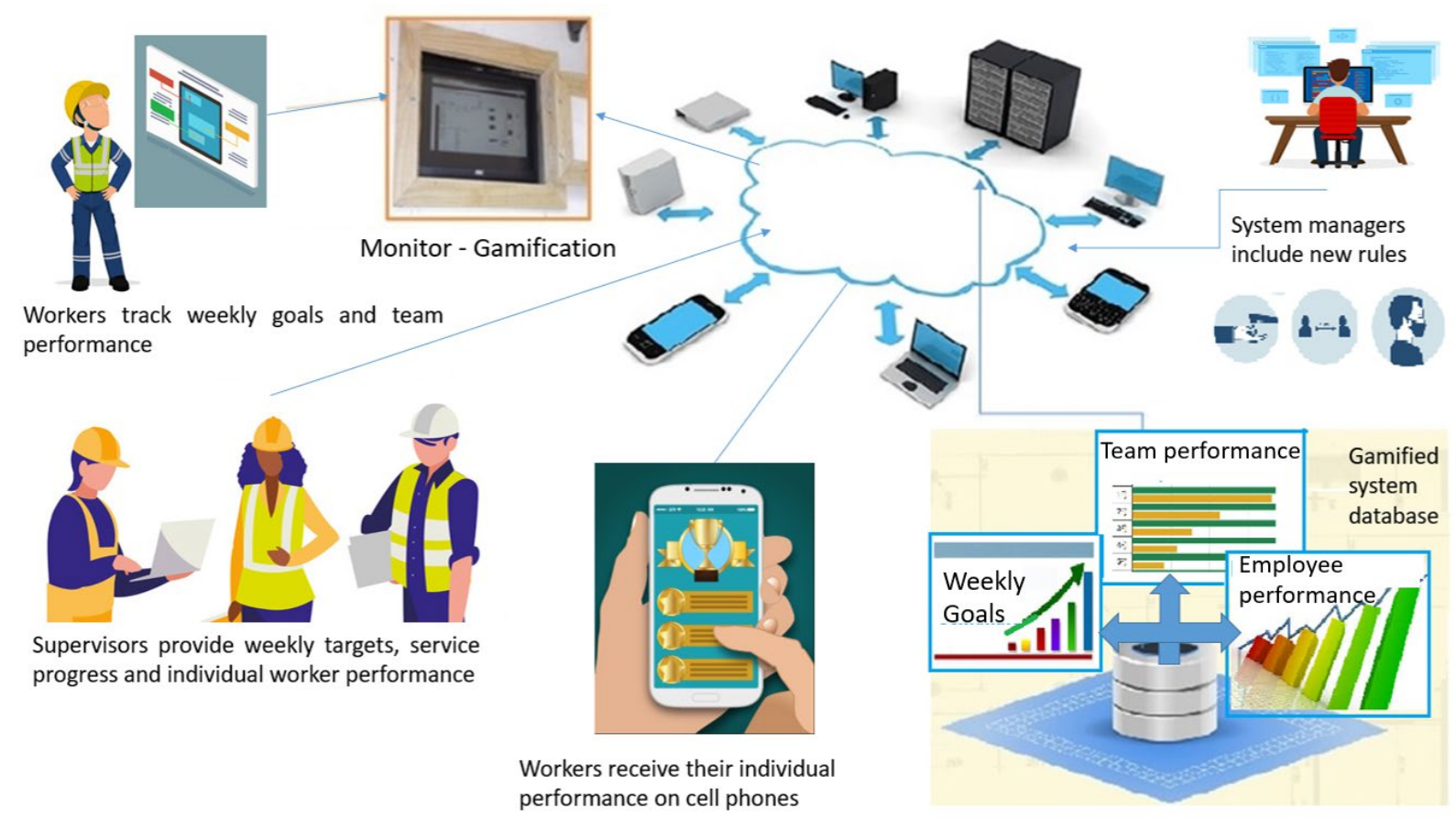

Source: Scheme built by the authors from public domain images

Feedback to the worker can be presented through color graphics Green (great), Yellow (reasonable), and Red (bad), already known and used in construction sites, or even by icons such as faces in the same colors (smiles) or other signs that connote performance. Thus, the employee can feel recognized, motivated, and understand the weekly goals, which should improve the team's performance.

\section{CONCLUSION}

The article aimed to present a proposal for a model for the implementation of gamification to improve production control in civil construction. To support this 
proposal, a field survey was carried out with 109 workers from which it was possible to establish a profile of the target audience to idealize a gamification model at the construction site to make the weekly goals more transparent and to motivate workers to meet them.

The idealized model proved to be flexible enough to allow the insertion of new rules as an example rule regarding the pandemic situation, for which the worker can have difficulty assimilating or motivation to comply with them.

This research contributes to the continuous improvement of the construction site to provide a more integrated and safer environment for carrying out the work, establishing more effective communication between managers and the workforce. Future work will be the modeling and validation of the system with a group of engineers and construction professionals to design the web version.

\section{REFERENCES}

1 SOUTO, Xênia Macedo. COVID-19. Recital-Revista de Educação, Ciência e Tecnologia de Almenara/MG, v. 2, n. 1, p. 12-36, 2020.

2 KOSKELA, Lauri. Application of the new production philosophy to construction. Stanford: Stanford university, 1992.

${ }^{3}$ VALENTE, Caroline Porto. Modelo para concepção de dispositivos visuais na gestão da produção na construção. 2017. (Dissertação de Mestrado) Universidade Federal do Rio Grande do Sul.

${ }^{4}$ EL-SABEK, Luai M.; MCCABE, Brenda Y. Coordination Challenges of Production Planning \& Control in International Mega-Projects: A Case Study. Lean Construction Journal, 2017.

${ }^{5}$ BRADY, D. A., TZORTZOPOULOS, P., ROOKE, J., FORMOSO, C. T., TEZEL, A Improving transparency in construction management: a visual planning and control model. Engineering, Construction and Architectural Management, 2018.

${ }^{6}$ LEITE, R. M. C., Costa, D. B., Neto, H. M. M.; Durao, F. A.Gamification technique for supporting transparency on construction sites: a case study. Engineering, Construction and Architectural Management, 2016.

${ }^{7}$ LEITE, R. M. C., Costa, D. B., Neto, H. M. M.; Vieira Lima. M. L. Gamificação: uma solução para melhoria da comunicação com os trabalhadores e da transparência da obra. In: Leite, Jessica e Suzart, Renaielma.O Universo da Engenharia Civil. Salvador, BA: Editora Mente Aberta, 2018 p. 150-166.

${ }^{8}$ BRADY, Denise Ann Using visual management to improve transparency in planning and control in construction. 2014. Tese de Doutorado. University of Salford.

${ }^{9}$ MORÊDA NETO, H.; Leite, R. M.; Costa, D. B.; Durão, F. Visual communication panels for production control using gamification techniques. In: Proceedings of the 22nd Annual Conference of the International Group for Lean Construction: Understanding and Improving Project Based Production. Oslo: IGLC. 2014.

10 DETERDING, S., SICART, M., NACKE, L., O'HARA, K.; DIXON, D. Gamification. using game-design elements in non-gaming contexts. In: CHI'11 extended abstracts on human factors in computing systems. 2011. p. 2425-2428 
11 HUOTARI, Kai; HAMARI, Juho. Defining gamification: a service marketing perspective. In: Proceeding of the 16th international academic MindTrek conference. 2012. p. 17-22.

12 HUOTARI, Kai; HAMARI, Juho. A definition for gamification: anchoring gamification in the service marketing literature. Electronic Markets, v. 27, n. 1, p. 21-31, 2017.

${ }^{13}$ DETERDING, Sebastian. The lens of intrinsic skill atoms: A method for gameful design. Human-Computer Interaction, v. 30, n. 3-4, p. 294-335, 2015.

14 HAMARI, Juho; KOIVISTO, Jonna; SARSA, Harri. Does gamification work? a literature review of empirical studies on gamification. In: 2014 47th Hawaii international conference on system sciences. leee, 2014. p. 3025-3034.

15 MORSCHHEUSER, Benedikt; HAMARI, Juho; KOIVISTO, Jonna. Gamification in crowdsourcing: a review. In: 2016 49th Hawaii International Conference on System Sciences (HICSS). IEEE, 2016. p. 4375-4384.

16 SEABORN, Katie; FELS, Deborah I. Gamification in theory and action: A survey. International Journal of human-computer studies, v. 74, p. 14-31, 2015.

17 ZICHERMANN, Gabe; CUNNINGHAM, Christopher. Gamification by design: Implementing game mechanics in web and mobile apps. " O'Reilly Media, Inc.", 2011.

18 WERBACH, Kevin; HUNTER, Dan. For the win: How game thinking can revolutionize your business. Wharton Digital Press, 2012.

19 SAILER, Michael; Hense, J. U.; Mayr, S. K.; Mandl, H. How gamification motivates: An experimental study of the effects of specific game design elements on psychological need satisfaction. Computers in Human Behavior, v. 69, p. 371-380, 2017.

${ }^{20} \mathrm{CHOU}$, Yu-kai. Actionable gamification: Beyond points, badges, and leaderboards. Packt Publishing Ltd, 2019.

21 SCHLEMMER, Eliane. Projetos de aprendizagem gamificados: uma metodologia inventiva para a educação na cultura híbrida e multimodal. Momento-Diálogos em Educação, v. 27, n. 1, p. 42-69, 2018.

${ }^{22}$ DETERDING, Sebastian. Gamification in management: Between choice architecture and humanistic design. Journal of Management Inquiry, v. 28, n. 2, p. 131-136, 2019.

23 KORN, Oliver; SCHMIDT, Albrecht. Gamification of business processes: Redesigning work in production and service industry. Procedia Manufacturing, v. 3, p. 3424-3431, 2015.

${ }^{24}$ LEITE, R. M. C. Uso da Gameficação para Melhoria do Planejamento e Controle de Obras. (Dissertação de Mestrado) Universidade Federal da Bahia 2014

25 WARMELINK, Harald; Koivisto;J., Mayer;I., Vesa, M; Hamari, J. Gamification of production and logistics operations: Status quo and future directions. Journal of Business Research, v. 106, p. 331-340, 2020.

26 DRESCH, Aline; LACERDA, Daniel Pacheco; JÚNIOR, José Antonio Valle Antunes. Design science research: método de pesquisa para avanço da ciência e tecnologia. Bookman Editora, 2015. 